\title{
Multiple Level Effects Of Imazethapyr On Leptodactylus Latinasus (Anura) Adult Frogs
}

Juan Manuel Pérez Iglesias ( $\square$ juanmapi@gmail.com )

Universidad Nacional de San Luis https://orcid.org/0000-0003-1399-4107

\section{Lara Zácari Fanali}

UNESP: Universidade Estadual Paulista Julio de Mesquita Filho

\section{Lilian Franco-Belussi}

UFMS: Universidade Federal de Mato Grosso do Sul

\section{Guillermo Sebastian Natale}

UNLP: Universidad Nacional de la Plata

\section{Classius De Oliveira}

Universidade Estadual Paulista: Universidade Estadual Paulista Julio de Mesquita Filho Julie Celine Brodeur

INTA: Instituto Nacional de Tecnologia Agropecuaria

Marcelo Luis Larramendy

Universidad Nacional de La Plata

\section{Research Article}

Keywords: Acute toxicity, Biomarkers integration, Dermal exposure, Imazethapyr herbicide, Leptodactylus latinasus

Posted Date: May 27th, 2021

DOI: https://doi.org/10.21203/rs.3.rs-227544/v1

License: (c) (1) This work is licensed under a Creative Commons Attribution 4.0 International License. Read Full License

Version of Record: A version of this preprint was published at Archives of Environmental Contamination and Toxicology on August 18th, 2021. See the published version at https://doi.org/10.1007/s00244-02100880-w. 


\section{Abstract}

Imazetapir is a herbicide used in soybean and corn crops worldwide. Ecotoxicological studies have shown that imazetapir promotes genotoxic, biochemical and individual effects in aquatic vertebrates. In this study, we evaluated the response of different biomarkers in adult specimens of Leptodactylus latinasus exposed under laboratory conditions to the imazetapir based-formulation Pivot ${ }^{\circledR} \mathrm{H}(10.59 \%$ Imazetapir) mimicking two possible real acute scenarios. Both exposure scenarios considered were the runoff simulation (scenario1: $10 \mathrm{mg} / \mathrm{L}$ ) and the direct spraying application (scenario2: $1000 \mathrm{mg} / \mathrm{L}$ ). Different endpoints were evaluated at several ecotoxicological levels after 48 and $96 \mathrm{~h}$ of exposure including individual (biometric indices and behavior alterations), histological (liver pigmentation and tissue alterations), biochemical (catalase, glutathione system and cholinesterase activities) and genotoxic effects (induction of micronuclei and nuclear abnormalities). The exposure to Pivot ${ }^{\circledR} \mathrm{H}$ during $48 \mathrm{~h}$, induced inhibition of the glutathione-S-transferase activity in scenario 1 and an increase of hepatic tissue alterations and acetyl-cholinesterase levels in scenario2. After $96 \mathrm{~h}$, we demonstrated that imazetapir formulation induced a decrease in melanin and hemosiderin, an increase in catalase activity and induction of micronuclei in scenario1 while in scenario2 there was a decrease in the hepatosomatic index, and an increase in liver alterations and melanin reduction. The multivariate analysis allows to correlate biomarkers at the same level in exposed specimens. Accordingly, we conclude that populations of L. latinasus could be at risk after real scenarios of exposure to pesticides corroborating that the species is a good model for ecotoxicological studies in the region.

\section{Introduction}

Pesticide applications are deemed critical to maintaining high agricultural output. By constrast, they can cause adverse effects in non-target organisms because they share target sites similar to the sites of action of pesticides (Howarth, 2000; Köhler and Triebskorn, 2013). For better pests control, new specific herbicides have been developed. Among them, imidazolinones are included. The imidazolinones are a group of widely used broad-spectrum herbicides employed for selective pre- or post-emergence weed control in a variety of crops. These herbicides fall into the class of acetolactate synthase (ALS)-inhibitors, an enzyme involved in the synthesis of branched-chain amino acids (Tan et al., 2005; Kawai et al., 2007; Lin et al., 2007). Imidazolinones are considered to have low toxicity in non-target animals included in the categories as slightly toxic (Class III) for the U.S. Environmental Protection Agency (U.S. EPA) (USEPA, 1989) and unlikely to be dangerous for the World Health Organization (Kegley et al., 2020).

Imazethapyr (IMZT) [5-ethyl-2-(4-isopropyl-4-methyl-5-oxo-4,5-dihydroimidazol-1H-2-yl) nicotinicacid] is an imidazolinone herbicide widely used in soybeans and corn crops genetically modified to be resistant to these herbicides. The recommended application rate of IMZT ranges between 0.8 to $1 \mathrm{~L} /$ ha for both aerial and terrestrial applications, respectively (CASAFE, 2013). IMZT has been classified as a slightly toxic (Class III) by the U.S. EPA (1989), and as a dangerous compound for the environment by the European Union (EU) (Kegley et al., 2020). Furthermore, they affirm that IMZT is an unsafe pesticide for the 
environment and be associated with adverse effect in humans such as irritant eyes, skin lessons and respiratory tract difficulties (Kegley et al., 2020).

At the same time, about IMZT-induced toxicity in non-target organisms very little is known. In this sense, low toxicity have been informed for the green alga Raphidocelis subcapitata (Sphaeropleales) and for aquatic invertebrates such as the phyllopoda Daphnia magna (Cladocera) after acute exposure (Kegley et al., 2020). In constrast, high levels of acute toxicity was reported in the gibbous duckweed Lemna gibba (Alismatales) (Magdaleno et al., 2015; Reimche et al., 2015; Kegley et al., 2020). Moreover, variation in sensitivity to IMZT has been reported in terrestrial invertebrates from low (earthworms) to high (honey bees) (Kegley et al., 2020). Also, the reports showed that IMZT is non toxic for fish such as the channel catfish Ictalurus punctatus (Siluriformes), the rainbow trout Oncorhynchus mykiss (Salmoniformes) and the bluegill Lepomis macrochirus (Perciformes) after acute exposures (Kegley et al., 2020). Furthermore, analyzing in aquatic vertebrates, Moraes et al. (2011) reported alterations on enzymes related to oxidative stress after $0.0148 \mathrm{mg} / \mathrm{L}$ exposure to both the active ingredient IMZT and to the IMZT-based commercial herbicide formulation Only ${ }^{\circledR}$ in hepatic tissues of the common carp Cyprinus carpio (Cypriniformes). In addition, inhibition of acetylcholinesterase (AChE) was informed after exposure to commercial formulations of IMZT in the Mozambique tilapia Oreochromis mossambicus (Cichliformes) (Pasha and Singh, 2005; Pasha, 2013). Recently, our research group has demonstrated the toxicological effects at genetic, biochemical and individual level in two local amphibian species as the Montevideo tree frog Boana pulchella and Leptodactylus latinasus (Anura) exposed to IMZT at their larval phase (PérezIglesias et al., 2015; Pérez-Iglesias et al., 2017; Pérez-Iglesias et al., 2018; Pérez-Iglesias et al., 2020). Particularly, we found alterations in several biomarkers such as primary DNA lesions and micronuclei (MNs) frequency, gluthatione-S-transferase (GST) alterations, morphological abnormalities and swimming performance. Thus, we were able to demonstrate that when the exposures of environmental stressors increases, IMZT-exposed organism move from homeostasis toward a stress status (PérezIglesias et al., 2015; Pérez-Iglesias et al., 2017; Pérez-Iglesias et al., 2018; Pérez-Iglesias et al., 2020). Finally, focusing on terrestrial vertebrates, IMZT has low or moderate acute toxicity when administered to Sprague Dawley rats and New Zealand white rabbits by oral or dermal route, respectively (Kegley et al., 2020).

Amphibians are non-target organisms of environmental stressors but also due to their special characteristics such as their permeable skin, position in trophic webs, shell-less eggs, exposed embryogenesis, free-living aquatic larvae, dependence upon two environments throughout their life history, and a narrow home range have been widely used as bioindicators of environmental quality (Blaustein and Wake, 1990; Stebbins and Cohen, 1995; Blaustein et al., 2011). Furthermore, the increasing use of environmental stressors (e.g. pesticides) has been claimed to be one of the main causes responsible for the recent decline in amphibians populations worldwide (Blaustein and Wake, 1990; Houlahan et al., 2000; Kiesecker et al., 2001; Beebee and Griffiths, 2005; Mann et al., 2009). Several studies have demonstrated that amphibians are negatively affected at the physiological, histological, biochemical and cytogenetic levels by living in agroecosystems where pesticides are continuously introduced (Mann et al., 2009; Shutler and Marcogliese, 2011; Hegde and Krishnamurthy, 2014). 
Particularly in Argentina, several authors have been reported evidences of alterations in anurans that inhabiting the agricultural Pampasic region, where large amount of pesticides are applying (Cabagna et al., 2006; Attademo et al., 2007; Peltzer et al., 2008; Attademo et al., 2011; Brodeur et al., 2011; Brodeur et al., 2012; Agostini et al., 2013; Sanchez et al., 2013; Attademo et al., 2014; Babini et al., 2015; Josende et al., 2015; Guerra and Aráoz, 2016). In this sense, amphibians are an important group of non-target organisms in Argentinean agricultural landscapes that can be exposed directly or residually to a variety of pesticides through plant material and soil (Mann et al., 2009; Brodeur et al., 2011; Brodeur et al., 2012; Van Meter et al., 2014; Suárez et al., 2016; Van Meter et al., 2019). Furthermore, amphibian terrestrial exposure to environmental stressors through dermal uptake may be a primary and a significant pathway (Van Meter et al., 2014; Van Meter et al., 2015; Van Meter et al., 2018; Van Meter et al., 2019). Also, have been demonstrated that dermal uptake processes of environmental stressors are more faster in anurans than in mammals, suggesting that for terrestrial amphibian life stages present in crop fields pesticide uptake through the skin might represent a likely exposure route (Brühl et al., 2013). Adult amphibians are known to move across terrestrial landscapes in search of breeding ponds and/or overwintering habitats (Brühl et al., 2013; Van Meter et al., 2018; Van Meter et al., 2019). This situation, particularly in agriculturally intensive areas, leads to the terrestrial amphibians to risk of dermal exposure due to soils or contaminated vegetation with pesticides (Van Meter et al., 2018; Van Meter et al., 2019). The primary route of exposure to pollutants of specimens of the species in agricultural habitats is via skin contact with soil or water principally by direct application, and secondly by runoff or ingestion of insects previously exposed (Pérez-Iglesias et al., 2016). However, few studies employing a battery of bioassays evaluating the effects of pesticides after dermal exposure on adults anurans have been reported worldwide (Brühl et al., 2013; Van Meter et al., 2014; Van Meter et al., 2015; Van Meter et al., 2018; Van Meter et al., 2019). In Neotropical regions, some studies revealed that the anurans sampled in agricultural landscapes had lowered body condition and increased stress responses, which may have related to the presence of environmental stressors (Brodeur et al., 2011; Brodeur et al., 2012).

Environmental exposures are quite complex and the implementation of a battery of biomarkers to biomonitor the status of amphibian populations is highly recommendable (Venturino and Pechen de D'Angelo, 2005; Newman, 2014). It is well documented that the use of biomarkers at different ecological levels could link environmental exposure with a wide range of deleterious biological responses of aquatic vertebrates (e.g. amphibians) and, the biomarkers also may be useful tools able to support environmental decisions before irreversible damage occurs in the ecosystem (Van der Oost et al., 2003; Vasseur and Cossu-Leguille, 2003; Sparling et al., 2010; Ossana et al., 2013; Josende et al., 2015).

In this context, the objective of the present study was to evaluate whether real-life exposures affect the anuran physiology and genetic material using several biomarkers in terrestrial adult of L. latinasus exposed under laboratory conditions to concentrations of the IMZT-based herbicide formulation Pivot $\mathrm{H} \circledast$ simulating realistic scenarios.

\section{Materials And Methods}




\subsection{Chemical reagents and determinations}

All Chemicals, reactives and solvents of analytical grade were purchased from Sigma Chemical Co. (St. Louis, MO) while Pivot $\mathrm{H}{ }^{\circledR}(10.59 \%$ w/v of IMZT, CAS 081335-77-5) was obtained from BASF Argentina S. A.

IMZT concentrations in bioassay solutions were analyzed by HPLC equipment in the CIM Institute (National University of La Plata, La Plata, Argentina) according to the procedures of Report 01-4134 by the U.S. Geological Survey. Samples from test nominal concentrations were taken and immediately measured after the solutions preparations $(0 \mathrm{~h})$ and $24 \mathrm{~h}$ thereafter. Detection limit of IMZT was $0.5 \mu \mathrm{g} / \mathrm{L}$.

\subsection{Test organisms and specimens recollection}

The urnero frog Leptodactylus latinasus (Jimenez de la Espada, 1875) (Anura, Leptodactylidae) is a small sized terrestrial species $(38-40 \mathrm{~mm}$ ) that hides under rocks or debris. Specimens feed on the insects encountered on the soil amongst the vegetation (Cei, 1980). Males of this species build small caves in the mud where they call females and eggs are laid in a foam nest where tadpoles begin their development and emerge when it is inundated by rains or overflowing brooks (Cei, 1980; Brodeur et al., 2011). Particularly, the species was chosen due to its particular characteristic of having reproductive and foraging activity within soybean, wheat and maize crops where its caves are built between the plants, in micro-reflections of depressions forming micro-spring ponds after the surface runoff. Furthermore, several authors (Agostini et al., 2016; Medina et al., 2016; Pérez-Iglesias et al., 2016; Suárez et al., 2016) have been employed and proposed $L$. latinasus as bioindicator species due to (1) is the most frequent species in Neotropical agroecosystems as well as non-disturbed areas, (2) their populations are not in risk (least concern; (Vaira et al., 2012; IUCN, 2020), and (3) easy to sampled and maintain in the laboratory. In addition, L. latinasus was used in previous ecotoxicological studies for the evaluation of individual, biochemical and cytogenetic biomarkers after IMZT and glyphosate exposure (Brodeur et al., 2011; Guerra and Aráoz, 2016; Pérez-Iglesias et al., 2016; Pérez-Iglesias et al., 2020). However, effects of IMZT in adults frogs testing multiple biomarkers are unknown.

The individuals of $L$. latinasus $(\mathrm{n}=60)$ were obtained in night collections from a typical Pampas unpolluted habitats, no large-scale agricultural activities, during breeding season (La Plata, Buenos Aires, Argentina $35^{\circ} 00^{\prime} 02^{\prime \prime} \mathrm{S}, 57^{\circ} 52^{\prime} 15^{\prime \prime} \mathrm{W}$ ). All collections from individuals were approved with permission from the Flora and Fauna Direction from the Buenos Aires Province (code 22500 - 22339/13) and treated in all procedures according to "Reference Ethical Framework for Biomedical Research: Ethical Principles for Research with Laboratory, Farm, and Wild Animals" (CONICET 2005). Adult males of L. latinasus were transported to the laboratory, weighted (average, $3.52 \pm 0.65 \mathrm{~g}$ ) and measured (snout-vent length average, $31.27 \pm 2.60 \mathrm{~mm}$ ). Afterwards, specimens were acclimated during 7 days in $2800 \mathrm{~cm}^{3}$ glass containers with water, controlling photoperiod $\left(16: 8 \mathrm{~h}\right.$ light/dark) and temperature $\left(25.0 \pm 1^{\circ} \mathrm{C}\right)$ without food supply.

\subsection{Experimental design and exposure protocol}


Two possible scenarios of environmental relevance were considered with a design to maximize herbicide uptake across the dermis by exposure of the frogs to acute pulses simulating the real-life environment where L. latinasus inhabiting as suggested by Van Meter $(2014 ; 2015 ; 2019)$. Experiments were carried out considering the mode of exposure previously adopted by Wang and Jia (2009) and Van Meter et al. following two plausible scenarios with runoff simulation (S1: $10 \mathrm{mg} I M Z T / L)$ and direct spraying application (S2: $1000 \mathrm{mg}$ IMZT/L). Briefly, before the start of bioassay, frogs were placed in a clean glass $20 \mathrm{~L}$ aquarium for a $24 \mathrm{~h}$ period of dehydration. This dehydration period was intended to facilitate the movement of water and xenobiotics throughout the anuran dermis because the rehydration start in the exposure bioassay, according to the suggestions of Van Meter et al. (2018). For each scenario, adults frogs were exposed to an acute pulse of the IMZT-based herbicide formulation consisting in immersing the entire specimens for $15 \mathrm{sec}$ to each herbicide concentrations (10 and $1000 \mathrm{mg}$ IMZT/L). The test solutions were prepared according to procedures proposed by U.S. EPA (1975). Also, negative control groups were prepared consisting of 10 frogs immersed in dechlorinated tap water and run in parallel to herbicide-exposed specimens. Immediately after exposure, each frog was placed individually in a $3 \mathrm{~L}$ glass flasks containing $200 \mathrm{~mL}$ base of fertile soil. Frogs were not fed throughout the experiment and were rehydrated by spraying dechlorinated tap water every $24 \mathrm{~h}$ to avoid frogs death due to drying (Van Meter et al., 2018). Evaluation of the proposed endpoints was performed 48 and $96 \mathrm{~h}$ after the acute pulse exposure. On each sampling time, all frogs were anesthetized, placed on ice and dissected according to directives and protocols detailed in the Guide for Care and Use of Laboratory Animals (Garber et al., 2011), and to the ethical procedures of the Ethical Committee from the National University of La Plata (code11/N619), "Reference Ethical Framework for Biomedical Research" (CONICET, 2005) and "Guide for Care and Use of Experimental Animals" (INTA, 2008). Experiments were performed in triplicate and 10 individuals were employed each time.

\subsection{Evaluations of endpoints}

To assess the effects induced by IMZT under two possible exposure scenarios, several endpoints were considered at different ecotoxicological levels, i.e., individual, histological, biochemical and cytogenetic.

\subsubsection{Individual endpoints}

Neotropical anurans' body condition was assessed using a method described by Brodeur et al. (2011; 2020). This method consists in examining the residuals from a regression of body mass against snoutvent length where the regression line obtained establishes the average body weight for a given length. Then an individual with a positive residuals considered to be in a good condition whereas an individual with a negative residuals regarded as having low energy (Schulte-Hostedde et al., 2005; Brodeur et al., 2011; Brodeur et al., 2020). To evaluate behavior sublethal endpoint, after 48 and $96 \mathrm{~h}$ of initial exposure, mobility and position of the frogs of each treatment were observed during $1 \mathrm{~min}$ in a polypropylene chamber $(30 \mathrm{~L})$ and posterior putted into a pool for examine swimming activity for another minute. Finally, hepatosomatic index ( $\mathrm{HSI}$ ) was calculated as the ratio of the liver weight respect to total body weight. After all the experiments the liver was weighed (before removing a histology fragment for histological endpoints) to obtain the HSI index using a precision scale $0.001 \mathrm{~g}$. 


\subsubsection{Histological endpoints}

Procedures followed previous reports for the species (Pérez-Iglesias et al., 2016). A half-portion of the liver was extracted and used for biochemical procedures (Sect. 2.4.3) while the other portion was put in solution Karnovsky fixative ( $0.1 \mathrm{M}$ phosphate buffer, $5 \%$ paraformaldehyde and $2.5 \%$ glutaraldehyde) at $\mathrm{pH} 7.2$ for $24 \mathrm{~h}\left(4^{\circ} \mathrm{C}\right)$ for histological procedures. Then, each liver sample was rinsed and cleaned with distilled water, placed in alcohol series to dehydrated and embedded in historesin. After, using a Leica RM 2265 microtome liver section were obtained by cutting randomly selected $2 \mu \mathrm{m}$-thick sections $(\sim 60$ sections of each liver). For mounting slides, approximately 20 liver sections were selected, totaling two slides by frog for histological analysis (liver tissue alterations and pigmentation of liver). One slide was stained with hematoxylin-eosin to evaluate liver alterations and melanin quantification. The second slide was incubated in acidic ferrocyanide for 15 minutes, stained with neutral red and eosin solutions for hemosiderin detection. Afterwards, histological sections were observed under a Leica DM4000 B microscope with an image capture system (Leica DFC 280).

\subsubsection{Liver tissue alterations}

Ten histological sections per sample were employed and liver tissue alterations was analyzed according to Çakici (2015) by evaluating: hyper vascularization or congestion (HV), enlargement of sinusoids (ES), mononuclear cell infiltration (MI), vacuolization (V) and necrosis in hepatocytes.

\subsubsection{Pigmentation of liver melanomacrophages (MMC)}

For pigmentation evaluation, for each liver sample ( $n=25$ micrographs) were analyzed using Image Pro Plus 6.0 software (Media Cybernetics, Inc., Rockville, MD). Based on the different staining intensity, the area occupied by melanin and hemosiderin pigment was quantified in the MMC (Pérez-Iglesias et al., 2016).

\subsubsection{Biochemical endpoints}

All procedures were made according to Brodeur et al. (2011) with minor modifications for microplates. Livers were homogenized in ice-cold $50 \mathrm{mM}$ tris buffer ( $1 \mathrm{mM}$ EDTA acid, $0.25 \mathrm{M}$ of sucrose, $\mathrm{pH}$ 7.4) with a Teflon-glass Potter-Elvehjem homogenizer. Then, the homogenates were centrifuged at $4{ }^{\circ} \mathrm{C}(10,000 \times \mathrm{g}$, $10 \mathrm{~min}$ ) to collect the supernatant while nuclei and cell debris was discarded. One portion of the supernatant was used for direct determination of hepatic contents of GSH and the rest portion of supernatant was stored at freezer $\left(220^{\circ} \mathrm{C}\right)$ until enzyme activities determination. Protein concentrations were determinated by the method of Lowry (1951) using bovine serum albumin as a standard. All enzymatic reactions and protein calibration curve were performed on microplates, and posterior reads of the enzymatic activities as well as the protein concentration were carried out by using a microplate reader (SPECTROstar Nano, BMG Labtech, Ortenberg, Germany).

\subsubsection{GSH determination}


Hepatic GSH contents were determined colorimetrically by quantifying the amount of 2-nitro-5thiobenzoic acid resulting from the interaction of GSH with dithiobis-2-nitrobenzoic acid (DTNB). Three $60 \mu \mathrm{L}$ aliquots of supernatant per sample were deproteinized separately by mixing with $120 \mu \mathrm{L}$ of acetonitrile. First of the three deproteinized aliquots served as a blank and mixed with $10 \mu \mathrm{L}$ of $\mathrm{N}$ ethylmaleimide, $110 \mu \mathrm{L}$ of acetonitrile and $60 \mu \mathrm{l}$ of liver sample. Microtubes with solutions were centrifuged at $4{ }^{\circ} \mathrm{C}(10,000 \times \mathrm{g}, 10 \mathrm{~min})$, and the supernatant was used for $\mathrm{GSH}$ determination. The reaction for GSH determination consisted of $200 \mu \mathrm{L}$ of saline buffer or PBS (50 mM, pH 7.5), $10 \mu \mathrm{L}$ of DTNB $(0.5 \mathrm{mM})$, and $160 \mu \mathrm{L}$ of supernatant with sample. Determination of GSH were made by using the average absorbance $(412 \mathrm{~nm})$ of replicates, after subtracting the absorbance of the blank and estimate the standard curve (Brodeur et al., 2011).

\subsubsection{GST activity determination}

The GST activity in the liver of L. latinasus was measured using 1-chloro-2, 4- dinitrobenzene (CDNB) as substrate. Determinations were performed in a reaction mixture containing $300 \mu \mathrm{L} \mathrm{GST}(30 \% \mathrm{~m} / \mathrm{v}$ of GSH in PBS, pH 7), $10 \mu \mathrm{L}$ CDNB (0.1 M) and $10 \mu \mathrm{L}$ of sample (dilution, 1:25 of pure supernatant:PBS). The colorimetric reaction absorbance $(340 \mathrm{~nm})$ was recorded during $2 \mathrm{~min}\left(37^{\circ} \mathrm{C}\right)$ and GST activity was calculated with molar extinction coefficient of $9.6 \mathrm{mM}^{-1} \mathrm{~cm}^{-1}$ (Brodeur et al., 2011).

\subsubsection{AChE activity determination}

Activity of hepatic acetyl cholinesterase (AChE) was determined by the Ellman method (1961). The reaction mixture consisted of $200 \mu \mathrm{L}$ of PBS (100 mM, pH 8), $10 \mu \mathrm{L}$ of acetylcholine $(1 \mathrm{mM}), 10 \mu \mathrm{L}$ of DTNB $(0.5 \mathrm{mM})$, and $50 \mu \mathrm{l}$ of sample (previously diluted $1 / 5 ; 200 \mu \mathrm{L}$ homogenized sample in $800 \mu \mathrm{L}$ of PBS). The kinetic absorbance $(412 \mathrm{~nm})$ was recorded during $3 \mathrm{~min}\left(37^{\circ} \mathrm{C}\right)$ and AChE activity was calculated using a molar extinction coefficient of $14,150 \mathrm{M}^{-1} \mathrm{~cm}^{-1}$.

\subsubsection{CAT activity determination}

The CAT activity in the liver of $L$. latinasus was determined by measuring the kinetic absorbance in microplates making reaction mixture of $300 \mu \mathrm{L}$ of PBS $(100 \mathrm{mM}, \mathrm{pH} 7), 10 \mu \mathrm{L}$ of $\mathrm{H}_{2} \mathrm{O}_{2}$ (dilution $0,5 \% \mathrm{v} / \mathrm{v}$, peroxide hydrogen $99 \%$ in distilled water) and $10 \mu \mathrm{L}$ of sample (dilution, 1:25 of pure supernatant:PBS). The change in the absorbance $(240 \mathrm{~nm})$ resulting from $\mathrm{H}_{2} \mathrm{O}_{2}$ consumption was recorded during 2 min $\left(37^{\circ} \mathrm{C}\right.$ ), using a molar extinction coefficient of $43.6 \mathrm{M}^{-1} \mathrm{~cm}^{-1}$ (Brodeur et al., 2011).

\subsubsection{Cytogenetic level. MNs and nuclear abnormalities on erythrocytes}

MN assay and blood analysis was conducted in accordance with original protocol (Fenech, 2007) with our minor modifications for this species (Pérez-Iglesias et al., 2016). Blood smears on microscope slides was confectioned by triplicate from each herbicide-exposed and non-exposed frogs stained during 12 min with $5 \%$ of Giemsa solution. MNs frequency was calculated in peripheral mature erythrocytes after acute pulse exposure in both scenarios. MNs were blind-scored from 1000 erythrocytes from each blood frog sample ( $\times 1000$ magnification). Also, the presence of other nuclear abnormalities in mature erythrocytes was evaluated for this species according our previous procedures (Pérez-Iglesias et al., 2016; Pérez- 
Iglesias et al., 2020). The following frequency of nuclear abnormalities were considered: notched nuclei (NNs), i.e., nuclei with vacuoles and appreciable depth into a nucleus without containing nuclear material; blebbed nuclei (BLs), i.e., cells with one nucleus presenting a relatively small evagination of the nuclear membrane which contains euchromatin; and erythroplastids (EPs), i.e., anucleated forms of circulating red blood cells. MNs and nuclear abnormalities frequencies are expressed as total number of alterations per 1000 cells and the examination criteria for MNs acceptance was determined following previously reports (Vera Candioti et al., 2010).

\subsection{Statistical analysis}

ANOVA one-way (analysis of variance) with post-hoc Dunnett test was performed to estimate the IMZT exposure-induced effects on body condition, organ index, livert tissue lesions, area occupied by melanin and hemosiderin pigment, liver enzymes activities (GST, CAT and AChE), hepatic GSH contents and frequencies of MNs and others nuclear abnormalities (response variables), at both exposure times evaluated (Zar, 2010). ANOVA assumptions were corroborated with Barlett test for the homogeneity of variances and $\chi 2$ test for normality. Then, data were logaritmic transformed to meet assumptions, in those cases that did not meet the assumptions of normality, a Kruskal-Wallis test was performed (Zar, 2010).

A principal component analysis (PCA) was performed considering each exposure scenario as a groping variable to improves interpretation of the results and allows obtain integral information of the biomarkers responses (or holistic vision). The integration of all biomarkers was made by using Components Principal Regression Analysis (Jackson, 1993; Jolliffe and Cadima, 2016). In addition, the relationship biomarkers and IMZT was evaluated with a correlation matrix (Pearson product moment correlation coefficient) by using simple linear regression. Tests of significance of the regression and correlation coefficients were performed following Zar (2010). The level of significance chosen was $a=0.05$ for all tests, unless indicated otherwise. Analyses were performed using the R software 6 v. 2.11.1 (R Core Team 2010).

\section{Results}

\subsection{Chemical determinations}

Chemical determinations demonstrated that concentrations of IMZT were stable over the 24-h period between daily re-newals of the test solution (concentration range $98 \pm 5 \%$ re-

covery). Specifically, HPLC analytic determinations of IMZT revealed a value equivalent to the real concentration of $10.86 \mathrm{IMZT} \mathrm{mg} / \mathrm{L} \pm 1.87$ (SD) and 1043.0 IMZT mg/L \pm 100.05 (SD), with respect to nominal concentration of 10 and $1000 \mathrm{IMZT} \mathrm{mg} / \mathrm{L}$, respectively; without variations in the $24 \mathrm{hs}$ of analysis $(P<0.05)$.

\subsection{Response of endpoints}


The results of the responses of all evaluated endpoints are summarized in Table 1. The responses after $48 \mathrm{~h}$ of each endpoint showed a decrease in GST activity in S1, while there was an increase in liver tissue alterations (HV and ES) as well as AChE activity in S2. In addition, after $96 \mathrm{~h}$, the observed effects were a marked decrease in the $\mathrm{HSI}$, melanin and hemosiderin and a concomitant increase in CAT activity and MNs frequencies in S1, while there was also a marked decrease in the HSI and melanin added to an increase in tissue alterations (HV and ES).

\subsubsection{Individual endpoints}

Evaluations of body condition at individual level after exposure to the herbicide IMZT did not reveal differences between frogs exposed in S1 and S2 respect to the control group at both times evaluated; however, were found that frogs exposed to IMZT scenarios shows alterations in HSI (Table 1). Specifically, frogs of L. latinasus in both scenarios presented the same body condition as specimens from the control group at both times. Significant differences were not found in body condition and behavior after both exposure times evaluated ( 48 and $96 \mathrm{~h})$ on each scenario $(p>0.05)$. On the other hand, the results showed significant differences between the exposure scenarios respect to control group for $48 \mathrm{~h}(p>0.05)$ but adverse effects with decreased HSI in both scenarios for S1 and S2 were detected $(p<0.05)$ at $96 \mathrm{~h}$.

\subsubsection{Histological endpoints}

Table 1 summarizes the results of all histological endpoints analyzed and the type of response for each exposure scenario considered. Particularly, in the analysis of liver tissue alteration was possible to detect only HV and ES according to Çakici (2015) at both 48 and $96 \mathrm{~h}$ (Fig. 1). Statistical analyzes of one-way ANOVA revealed that both alterations occurred at 48 and $96 \mathrm{~h}$ only in $\mathrm{S} 2(p<0.05)$. Regarding the analysis of pigments on liver MMC, a decrease in melanin and hemosiderin was observed at $96 \mathrm{~h}$ (Table 1). Specifically, the area of melanin and hemosiderin in liver MMC did not shown significant differences when comparing frogs treated with IMZT respect to control group $(p>0.05)$ after $48 \mathrm{~h}$. However, a significant decrease of the melanin area was detected in both scenarios after $96 \mathrm{~h}(p<0.05)$. On the other hand, the results showed significant differences with a decrease of the pigmented area of hemosiderin in liver MMC only in frogs of the $S 1(p<0.05)$ but not in frogs of the S2 $(p>0.05)$ after $96 \mathrm{~h}$.

\subsubsection{Biochemical endpoints}

Table 1 summarizes the results of biochemical endpoints analyzed and the type of response respect to control group in each exposure scenario considered after 48 and 96 of exposure. No effects by IMZT exposure were detected in GSH activity $(p>0.05)$ after $48 \mathrm{~h}$. However, the results showed a decrease in the activity of GST enzyme in frogs of the $S 1(p<0.05)$ and a significant increase in the activity of AChE $(p<0.05)$ in frogs of the 2 . Nevertheless, analysis did not reveal a significant difference in the activity of CAT activity by IMZT treatment when comparing both scenarios respect to control group $(p>0.05)$ after $48 \mathrm{~h}$. On the other hand, when analyzing the response of the enzymes after $96 \mathrm{~h}$ in frogs exposed to IMZT in both scenarios, there was not a significant alteration in the activity of GSH, GST and AChE with respect 
to the control group. However, analysis showed that CAT activity increases by treatment with IMZT in frogs of the $\mathrm{S} 1(p<0.01)$.

\subsubsection{Cytogenetic level endpoints}

At the cellular level, the results from the analysis of MNs and nuclear abnormalities revealed that IMZT is able to induce MNs at $96 \mathrm{~h}$ but not nuclear abnormalities in L. latinasus adult erythrocytes (Table 1). Particularly, a significant increase in the frequency of MNs was observed in S1 treated group but not in S2 $(p>0.05)$ when compared to the control group $(p<0.01)$ only at $96 \mathrm{~h}$. On the other hand, significant differences by IMZT-treatment were not detected respect to the control group when frequency of nuclear abnormalities in erythrocytes was analyzed at both scenarios and in both times evaluated $(p>0.05)$.

\subsection{Integration of biomarkers by PCA analysis}

First, a PCA with an exploratory aim was carried out with all the evaluated endpoints that were standardized prior to the analysis. In a second stage, only those variables that showed significant differences $(p<0.05)$ were selected with respect to the control groups after the ANOVA and Dunnett test and were called biomarkers.

The analyzes obtained of the reduction of dimensionalities in L. latinasus adults by means of the PCA revealed an evident differentiation between the IMZT-groups treated in different scenarios respect to the negative control which is explained by the correlation and integral response between the biomarkers used at 48 and $96 \mathrm{~h}$. In general, when analyzing the response of the 4 biomarkers (HV, ES, GST and AChE) at different levels of organization (histological and biochemical) and their correlation by the PCA at $48 \mathrm{~h}$, the analysis showed that the biomarkers are organized into 3 main components that explain $86.71 \%$ (PC1 = $47.58 \%$ and PC2 $=39.13 \%$ ) of the variability of the data. In addition to this, according to the response expressed by the biomarkers here evaluated, it was possible to determine an increasing gradient of concentrations along the acute pulse scenarios (from S1 to S2) with respect to the negative control (Fig. 1A). Specifically, the separation of the control group from S1 and S2 was due to a greater extent by the response of the biochemical biomarkers that contribute to the variability of PC1 and the histological biomarkers that contributed variability to the axis of PC2 (Fig. 1A). From these analyzes, it was also possible to show significant positive correlations between histological biomarkers with each other $(r=$ 0.52 ; $P<0.05)$ and between both biochemical biomarkers, AChE and GST $(r=0.88 ; P<0.05)$. On the other hand, the analyzes revealed that after $96 \mathrm{~h}$ there is a significant differentiation in the response of the biomarkers that explain the PC1 since they allow the negative control group to be separated from the S2 $(P<0.05)$, as well as the biomarkers that contribute to the PC2 axis that allow the control group to be separated from S1 $(P<0.05)$ and S2 $(P<0.001)$. Also, the correlation obtained by the PCA of the 7 biomarkers ( $\mathrm{HSI}, \mathrm{ES}, \mathrm{HV}$, melanin, haemosiderin, CAT and MNs) that responded after $96 \mathrm{~h}$ to the acute pulse of IMZT at the different levels of organization (individual, histological, biochemical and cytogenetic), showed that these are organized into 3 main components that explain $63.77 \%$ (PC1 = $29.55 \%, \mathrm{PC} 2=20.29 \%$ and PC3 $=13.93 \%$ ) of the variability of data. From the response biomakers shown, it was possible to determine two large subgroups characterized by the negative control and the worst scenario (S2) (Fig. 1B). Here, the separation of the control group from S2 was largely due to the response 
of the MNs, melanin of the MMC, ES and HV (which separate the subgroups on the axis of PC1) and from $\mathrm{HSI}, \mathrm{CAT}$ and hemosiderin in the MMC (which separate the subgroups on the axis of PC2) (Fig. 1B). From these analyzes, it was also possible to show significant positive correlations between histological biomarkers such as ES and HV $(r=0.39 ; \mathrm{P}<0.05)$ as well as significant negative correlations between MNs and ES $(r=-0.40 ; \mathrm{P}<0.05)$.

\section{Discussion}

Experiments in L. latinasus adults simulating real-life exposure scenarios demonstrate the potential adverse effect on the physiology and individual parameters of Neotropical anurans. Particularly, as mentioned in the introduction in other groups of organisms, few laboratory studies have evaluated adverse biological effects by IMZT and less in realistic exposure routes in juvenile and adult anurans, some examples are Rana esculenta (Quaranta et al., 2009), Sclerophrys regularis (Ezemonye and Tongo, 2010), Rana temporaria (Leiva-Presa and Munro Jenssen, 2006; Brühl et al., 2013), Rana pipiens (Selcer and Verbanic, 2014; Abercrombie et al., 2020), Acris crepitans, Gastrophryne carolinensis and Hyla versicolor(Van Meter et al., 2014), Hyla gratiosa and Hyla cinerea (Van Meter et al., 2014; Van Meter et al., 2015), Lithobates sphenocephala and Anaxyrus fowleri (Van Meter et al., 2014; Glinski et al., 2018), Lithobates clamitans (Edge et al., 2011; Van Meter et al., 2018), Anaxyrus americanus (Van Meter et al., 2015; Abercrombie et al., 2020). However, studies in Neotropical anurans affected by environmental stressors using various biomarkers at different organization levels are scarce and using other species such as Boana pulchella (Brodeur et al., 2011; Brodeur et al., 2012) and Rhinella arenarum (Castillo et al., 1991; Castillo et al., 2005; Lajmanovich et al., 2018). At this point, this is the first laboratory work evaluating and integrating the effects of pesticidas at multiple biological scales in adults bioindicator species from agricultural environments and to be applied as early detection tools.

Evaluating the individual parameters, a decrease in L. latinasus HSI was observed due to exposure to IMZT in both scenarios. These results reinforce the idea of using these end points as biomarkers at the individual level in adult anurans that are in stressful situations in the environments they inhabit (Brodeur et al., 2012). In particular, these authors report that adults of $B$. pulchella that inhabit agroecosystems present a reduction in $\mathrm{HSI}$ and explain that this particular response is consistent with stress situations such as droughts, poor nutrition or even exposure to different pesticides. The results presented in this study provide new evidence on L. latinasus as a model species to evaluate this type of biomarker not only in disturbed environments but also in laboratory bioassays.

The histological effects of this study demonstrate for the first time that IMZT produces liver lesions such as HV and AS and affects hepatic MMC in L. latinasus. Specifically, IMZT induced alterations in the area occupied by the pigments melanin and hemosiderin in the adult liver of L. latinasus, corroborating the usefulness of using these pigments in MMC as histological biomarkers against the action of pesticides as previously reported for this species (Pérez-Iglesias et al., 2016). It is important to mention that other authors have highlighted the importance of determine the effects of environmental stressors in detoxification organs due to maintain the homeostasis in aquatic vertebrates (McDiarmid and Altig, 1999; 
Păunescu et al., 2010; Çakici, 2015). In this study, we observed an increase in the frequency of liver alterations (HV and ES) for both scenarios. According to Gürkan and Hayretdağ (2012), this situation may be an indication of irreversible damage that consequently ends in hepatocellular degeneration. Several studies carried out in anurans support this idea since they have shown that high concentrations of pesticides cause damage to liver structures that lead to an increase in the rate of hepatic cell apoptosis and it has even been pointed out that principles of carcinogenesis may be associated with processes such as hypervascularization (Păunescu et al., 2010; Zaya et al., 2011; Çakici, 2015; Pérez-Iglesias et al., 2016). In addition, the analysis of the histological biomarkers in adults showed alterations in the pigments of the hepatic MMC by exposure to IMZT in S1 and S2 after $96 \mathrm{~h}$ exposure. The MMC are widely used to describe effects of environmental stressors (De Oliveira et al., 2017), and particularly in Leptodactylidae adults species (Pérez-Iglesias et al., 2016; Fanali et al., 2018). These results are consistent with previous studies carried out in anurans that demonstrate the alteration produced in the hepatic pigmentary system (MMC) by environmental stressors (Păunescu et al., 2010; Zaya et al., 2011; Gürkan and Hayretdağ, 2012; Franco-Belussi et al., 2013; Çakici, 2015; Pérez-Iglesias et al., 2016; De Oliveira et al., 2017). In general, MMC and its associated pigments such as melanin and hemosiderin are important in catabolic processes as an immune response, as detoxifiers and as protectors against ROS (Fenoglio et al., 2005; Franco-Belussi et al., 2013). However, an increase in MMC may be due to increased oxidative damage that occurs in cell membranes, increased cell death processes by the accumulation of lipofuscin within MMC (Couillard and Hodson, 1996; Fenoglio et al., 2005; Franco-Belussi et al., 2013) or due to the ability of this cellular defense system to eliminate waste due to an increase in phagocytic activity (Agius and Roberts, 2003; Franco-Belussi et al., 2013). Moreover, the results obtained in this work show that at $96 \mathrm{~h}$ there is a significant decrease in the area of the pigments melanin and hemosiderin in the hepatic MMC. According to previous studies, the decrease in these pigments is related with a reduction in phagocytic and protective activity against oxidizing agents of $\mathrm{MMC}$ in the liver (Fenoglio et al., 2005; Pérez-Iglesias et al., 2016; Fanali et al., 2018; Franco-Belussi et al., 2020). Focusing on the response of the catabolic pigment hemosiderin in S1, this work again reports similar results to those previously described for us in this species after herbicide exposure (Pérez-Iglesias et al., 2016). The decrease of hemosiderin pigment, due to the herbicide exposure, may be related to more severe damages that involve alterations in the hepatic catabolic processes inhibiting the recycling of ferric compounds related to the erythrocatetic function (Agius and Roberts, 2003). This statement can be corroborated by the significant increase in the frequency of MNs in erythrocytes of circulating blood cells, which would indicate alterations in erythrocateresis making cell renewal impossible, a function that depends on hepatic MMC in anurans (Agius and Roberts, 2003; Fenoglio et al., 2005). In this sense, the physiology and well-being or fitness of anurans exposed to pesticides would be negatively affected by the inability of the liver to eliminate or detoxify xenobiotics and damaged cellular components of the body (PérezIglesias et al., 2016). In this context, we consider that MMC are biomarkers of the health status of amphibians at the histological and cellular level in adults.

Analyzing the biochemical aspect, IMZT is also capable of inducing alterations in AChE activity in $L$. latinasus adults. In this sense, our results corroborate the same effects reported in fish by Pasha and 
Singh (2005), Moraes et al. (2011) and Pasha (2013), where IMZT alters the cholinergic system of local aquatic vertebrates. Oxidative stress refers to the imbalance due to excess ROS or oxidants over the cell's ability to carry out an effective antioxidant response. ROS are highly reactive species that can affect membrane lipids and nucleic acids, so regulating the delicate balance between ROS production and the activation of antioxidant cell defenses, such as CAT and GST enzymes, is essential to maintain cell viability (because they participate in the elimination of ROS) (Ferrari et al., 2008). In particular, the significant increase in CAT in adults of $L$. latinasus suggests that this enzyme acts as one of the main antioxidant defenses for these organisms against the action of a herbicide (Ferrari et al., 2011) with prooxidant characteristics such as IMZT in its Pivot ${ }^{\circledR} \mathrm{H}$ formulation (Moraes et al., 2011). Added to this, the increase in CAT would be considered a beneficial response in a stress situation since it prevents oxidation in cells before the respiratory system takes an active role in the gas exchange of anti-oxidative defense (Ferrari et al., 2011). On the other hand, the decrease in GST activity demonstrates an enzymatic inhibition of the dominant antioxidant defense system of these organisms (Ferrari et al., 2011). The decrease in GST would lead to the deactivation of detoxifying systems that counteract the damaging effects of ROS. Specifically, GST activity is involved in phase II biotransformation of xenobiotics in conjunction with the CYP-450 dependent monooxygenase system and thus prevents oxidative damage after acute exposure (Attademo et al., 2007; Ferrari et al., 2008; Ferrari et al., 2011). In this case, the role of GST is inhibited at $48 \mathrm{~h}$, which could lead to an increase in oxidative stress by IMZT exposure.

Finally, if we consider the response of histological biomarkers, we could think that since antioxidant enzyme systems do not respond (the case of CAT) or are inhibited (the case of GST) for that concentration and at that time, the antioxidant response would be in charge of $\mathrm{MMC}$ and its pigments, at least after $48 \mathrm{~h}$ of exposure. On the other hand, after $96 \mathrm{~h}$, in S1 there is an increase in CAT that would indicate that this is the antioxidant system that prevails over the function of MMC since the concentration of the stressor is lower. However, the situation is different in S2 (higher concentration) since the antioxidant enzymes evaluated do not respond to the action of the herbicide, there is only a cytoprotective function and liver damage such as HV and AS are recorded. In summary, in high concentrations of IMZT the liver damage is severe. In this situation, the hepatic enzyme systems and $\mathrm{MMC}$ lose their physiological response capacities to maintain cell renewal processes and antioxidant and detoxifying functions (Brodkin et al., 2007).

It should also be note that IMZT produces cytogenetic damage in L. latinasus adults. It is important to highlight that genomic instability plays a fundamental role in the decrease of the state of health or wellbeing in the populations of aquatic vertebrates (Barni et al., 2007; Jha, 2008). When DNA damage occurs, either due to an increase in MNs frequencies, nuclear alterations or damage direct in the DNA, this situation can end with cell death and lead to severe pathophysiological situations that increase physiological stress (Barni et al., 2007; Çavaş and Könen, 2007; Jha, 2008). However, another scenario can occur if the damaged cells survive. In this case, damaged cells that are not repaired or that have undergone poor repair will also have immediate adverse effects on the well-being and health of these organisms, which may ultimately result in decreased survival and long-term population effects (Barni et al., 2007; Jha, 2008).

Page $14 / 25$ 
In recent years, Newman (2014) highlighted the importance of evaluating the correlation of biomarkers as a whole and not separately. This information helps to understand not only the susceptibility of organisms to environmental stressors but also their mode of action and toxicity, which can later be used as early warning signals in environments that are disturbed or contaminated by the presence of environmental stressors (Newman, 2014; Pérez-Iglesias et al., 2020). In this sense, the ecotoxicological information that evaluates the correlation of adverse effects at different levels of biological organization is scarce. In this work, the multivariate analysis using a battery of biomarkers related to the responses at different levels of biological organization allows generate a novel information not provided by the individual and separate analysis of each biomarker. Furthermore, these results show that the endpoints evaluated respond to the concept of biomarkers proposed by Walker et al. (2009) who affirms that the analyzed end points are useful biomarkers to use.

Added to this, the PCA analysis from this study clearly allowed us to observe the separation between those frogs exposed to IMZT and the control group. This situation shows that the adverse effects of IMZT induce alterations in the physiological responses evidenced when evaluating biomarkers at different levels of biological organization. The holistic approach of multivariate analysis allows the evaluation of multiple endpoints simultaneously and facilitates the general and particular understanding of the various effects of experimental exposure to an environmental stressor. This is an advantage for this type of analysis in contrast to the separate information provided by conventional analyzes. In conclusion, and in agreement with other authors (Van der Oost et al., 2003; Newman, 2014), we recommend the use of this type of approach for ecotoxicological studies since it allows us to discern the groups of anurans that were exposed to environmental stressors from those that were not exposed.

Focusing on the ecological importance of experimental design, a first acute scenario (S1) simulate surface runoff of pesticide occurs and contaminated water income to breeding sites (caves in the ground) of the frogs. It is important to note that the highest concentrations of IMZT in runoff water occurred near the site of herbicide application, when the amount of IMZT transported by runoff did not exceed 3\% and storage of rainwater inside the soil (Dias Martini et al., 2013). A second scenario (S2) considered the worst-case scenario exposure where a direct application to the frog occurs to a concentration of the herbicide recommended by the manufacturer on the letterhead (e.g., the frog emerging from the cave and sprayed with the herbicide) (Van Meter et al., 2014). In these contexts, it is observed that after a realistic acute exposure of $L$. latinasus adults, there was a significant increase in cytogenetic damage in the proposed situation of surface runoff (S1) and the species presented more severe effects (biochemical damage, histological and individual) in the worst exposure situation considered, direct exposure or S2. We understand that the cytogenetic biomarker evaluated on this occasion (MNs) is presented as an early signal, responding in situations of low herbicide concentrations, before irreversible damage occurs at higher levels of organization. In addition to this, if the particular habit of life of this species is considered, we can understand that MNs in this case would be a valid tool to use in monitoring with $L$. latinasus given that a surface runoff event is the most likely exposure situation after runoff events due to heavy rains. At this point, IMZT could be a risk factor for $L$. latinasus 
populations. Finally, further research of this kind should be developed to understand the impact of pesticides on local populations of anurans.

\section{Abbreviations}

AChE, acetylcholinesterase; BL, blebbed nucleus; BN, binucleated cell; CAT, catalase; ES, enlargement of sinusoids; GST, gluthatione-S-transferase; GSH, reduced glutathione; $\mathrm{HSI}$, hepatosomatic index; HV, vascularization or congestion; IMZT, imazethapyr; LB, lobed nucleus; MMC, melanomacrophages; MNs, micronuclei; NT, notched nucleus; PCA, principal component analysis.

\section{Declarations}

\section{ACKNOWLEDGEMENTS}

This study was supported by grants from the National University of La Plata (Grants 11/N817 and 11/N847) of Argentina. The National Council for Scientific and Technological Research (CONICET) from Argentina and Graduate Program of UNLP to provided funding for JMPI to carry out the investigations and doctoral studies. CO received a fellowship (304552/2019-4) from CNPq - Conselho Nacional de Desenvolvimento Científico e Tecnológico. We also thank GAECI (Advisory Office on Scientific Writing in English), for their help in the idiomatic revising of the English language in this work.

\section{References}

1. Abercrombie SA, de Perre C, lacchetta M, Flynn RW, Sepúlveda MS, Lee LS, Hoverman JT (2020) Sublethal Effects of Dermal Exposure to Poly-and Perfluoroalkyl Substances on Postmetamorphic Amphibians. Environmental Toxicology and Chemistry

2. Agius C, Roberts RJ (2003) Melano-macrophage centres and their role in fish pathology. J Fish Dis 26:499-509

3. Agostini MG, Kacoliris F, Demetrio P, Natale GS, Bonetto C, Ronco AE (2013) Abnormalities in amphibian populations inhabiting agroecosystems in northeastern Buenos Aires Province, Argentina. Diseases of Aquatic Organisms 104:163-171

4. Agostini MG, Saibene PE, Roesler I, Bilenca D (2016) Amphibians of northwestern Buenos Aires province, Argentina: checklist, range extensions and comments on conservation. Check List 12, 1998

5. Attademo AM, Bionda CL, Peltzer PM, Lajmanovich RC, Seib SN, Basso A, Junges CM (2014) Edad, tamaño corporal en la madurez sexual, longevidad y potencial reproductivo de Leptodactylus latinasus y Leptodactylus mystacinus en un cultivo de soja y un bosque nativo del centro este de Argentina. Revista Mexicana de Biodiversidad 85, 315-317

6. Attademo AM, Cabagna-Zenklusen MC, Lajmanovich RC, Peltzer PM, Junges CM, Bassó A (2011) Besterase activities and blood cell morphology in the frog Leptodactylus chaquensis (Amphibia: 
Leptodactylidae) on rice agroecosystems from Santa Fe Province (Argentina). Ecotoxicology 20:274-282

7. Attademo AM, Peltzer PM, Lajmanovich RC, Cabagna M, Fiorenza G (2007) Plasma B-esterase and glutathione S-transferase activity in the toad Chaunus schneideri (Amphibia, Anura) inhabiting rice agroecosystems of Argentina. Ecotoxicology 16:533-539

8. Babini MS, Bionda CL, Salas NE, Martino AL (2015) Health status of tadpoles and metamorphs of Rhinella arenarum (Anura, Bufonidae) that inhabit agroecosystems and its implications for land use. Ecotoxicol Environ Saf 118:118-125

9. Barni S, Boncompagni E, Grosso, Bertone V, Freitas I, Fasola M, Fenoglio C (2007) Evaluation of Rana snk esculenta blood cell response to chemical stressors in the environment during the larval and adult phases. Aquat Toxicol 81:45-54

10. Beebee TJC, Griffiths RA (2005) The amphibian decline crisis: a watershed for conservation biology? Biol Cons 125:271-285

11. Blaustein AR, Han BA, Relyea RA, Johnson PTJ, Buck JC, Gervasi SS, Kats LB (2011) The complexity of amphibian population declines: understanding the role of cofactors in driving amphibian losses. Annals of the New York Academy of Sciences 1223, 108-119

12. Blaustein AR, Wake DB (1990) Declining amphibian populations: a global phenomenon? Trends in Ecology Evolution 5:203-204

13. Brodeur JC, Candioti JV, Soloneski S, Larramendy ML, Ronco AE (2012) Evidence of reduced feeding and oxidative stress in common tree frogs (Hypsiboas pulchellus) from an agroecosystem experiencing severe drought. Journal of Herpetology 46:72-78

14. Brodeur JC, Damonte MJ, Vera Candioti J, Poliserpi MB, D'Andrea MF, Bahl MF (2020) Frog body condition: Basic assumptions, comparison of methods and characterization of natural variability with field data from Leptodactylus latrans. Ecol Ind 112:106098

15. Brodeur JC, Suarez RP, Natale GS, Ronco AE, Zaccagnini ME (2011) Reduced body condition and enzymatic alterations in frogs inhabiting intensive crop production areas. Ecotoxicol Environ Saf 74:1370-1380

16. Brodkin MA, Madhoun $\mathrm{H}$, Rameswaran M, Vatnick I (2007) Atrazine is an immune disruptor in adult northern leopard frogs (Rana pipiens). Environmental Toxicology Chemistry: An International Journal 26:80-84

17. Brühl CA, Schmidt T, Pieper S, Alscher A (2013) Terrestrial pesticide exposure of amphibians: An underestimated cause of global decline? Sci Rep 3:1135

18. Cabagna MC, Lajmanovich RC, Peltzer PM, Attademo AM, Ale E (2006) Induction of micronuclei in tadpoles of Odontophrynus americanus (Amphibia: Leptodactylidae) by the pyrethroid insecticide cypermethrin. Toxicol Environ Chem 88:729-737

19. Çakici Ö (2015) Histopathologic changes in liver and kidney tissues induced by carbaryl in Bufotes variabilis (Anura: Bufonidae). Experimental and Toxicologic Pathology 67, 237-243 
20. CASAFE (2013) Guía de Productos Fitosanitarios para la República Argentina. in: Fertilizantes Cd.S.A.y. (Ed.). CASAFE, Buenos Aires

21. Castillo G, Chanampa Y, Orce G (2005) Effect of mercuric chloride on electrical parameters and anion fluxes in the toad skin. Comp Biochem Physiol C: Toxicol Pharmacol 140:21-27

22. Castillo GA, Coviello A, Orce GG (1991) Effect of theophylline on the electrolyte permeability of the isolated skin of the toad Bufo arenarum. Archives Internationales de Physiologie, de Biochimie et de Biophysique 99, 257-264

23. Çavaş T, Könen S (2007) Detection of cytogenetic and DNA damage in peripheral erythrocytes of goldfish (Carassius auratus) exposed to a glyphosate formulation using the micronucleus test and the comet assay. Mutagenesis 22:263-268

24. Cei JM (1980) Amphibians of Argentina. New Series Monografia, Università degli Studi di Firenze

25. CONICET (2005) Reference Ethical Framework for Biomedical Research: Ethical Principles for Research with Laboratory, Farm, and Wild Animals. in: Council, NS.a.TR (ed)

26. Couillard CM, Hodson PV (1996) Pigmented macrophage aggregates: A toxic response in fish exposed to bleached-kraft mill effluent? Environmental Toxicology and Chemistry. An International Journal 15:1844-1854

27. De Oliveira C, Franco-Belussi L, Fanali LZ, Santos LR (2017) Use of melanin-pigmented cells as a new tool to evaluate effects of agrochemicals and other emerging contaminants in Brazilian anurans. Ecotoxicology and Genotoxicology: Non-traditional Terrestrial Models 32, 125

28. Dias Martini LF, Mezzomo RF, de Avila LA, Massey JH, Marchesan E, Zanella R, Peixoto SC, Refatti JP, Cassol GV, Marques M (2013) Imazethapyr and imazapic runoff under continuous and intermittent irrigation of paddy rice. Agric Water Manag 125:26-34

29. Edge CB, Gahl MK, Pauli BD, Thompson DG, Houlahan JE (2011) Exposure of juvenile green frogs (Lithobates clamitans) in littoral enclosures to a glyphosate-based herbicide. Ecotoxicol Environ Saf 74:1363-1369

30. Ellman GL, Courtney KD, Andres V, Featherstone RM (1961) A new and rapid colorimetric determination of acetylcholinesterase activity. Biochem Pharmacol 7:88-95

31. Ezemonye L, Tongo I (2010) Sublethal effects of endosulfan and diazinon pesticides on glutathioneS-transferase (GST) in various tissues of adult amphibians (Bufo regularis). Chemosphere 81:214217

32. Fanali LZ, Franco-Belussi L, Bonini-Domingos CR, de Oliveira C (2018) Effects of benzo [a] pyrene on the blood and liver of Physalaemus cuvieri and Leptodactylus fuscus (Anura: Leptodactylidae). Environmental Pollution 237, 93-102

33. Fenech M (2007) Cytokinesis-block micronucleus cytome assay. Nat Protoc 2:1084-1104

34. Fenoglio C, Boncompagni E, Fasola M, Gandini C, Comizzoli S, Milanesi G, Barni S (2005) Effects of environmental pollution on the liver parenchymal cells and Kupffer-melanomacrophagic cells of the frog Rana esculenta. Ecotoxicol Environ Saf 60:259-268 
35. Ferrari A, Anguiano L, Lascano C, Sotomayor V, Rosenbaum E, Venturino A (2008) Changes in the antioxidant metabolism in the embryonic development of the common South American toad Bufo arenarum: Differential responses to pesticide in early embryos and autonomous-feeding larvae. $\mathrm{J}$ Biochem Mol Toxicol 22:259-267

36. Ferrari A, Lascano C, Pechen de D'Angelo, AM, Venturino A (2011) Effects of azinphos methyl and carbaryl on Rhinella arenarum larvae esterases and antioxidant enzymes. Comp Biochem Physiol C: Toxicol Pharmacol 153:34-39

37. Franco-Belussi L, de Lauro Castrucci AM, de Oliveira C (2013) Responses of melanocytes and melanomacrophages of Eupemphix nattereri (Anura: Leiuperidae) to Nle 4, D-Phe 7-a-melanocyte stimulating hormone and lipopolysaccharides. Zoology 116:316-324

38. Franco-Belussi L, Provete DB, Borges RE, De Oliveira C, Santos LR (2020) Idiosyncratic liver pigment alterations of five frog species in response to contrasting land use patterns in the Brazilian Cerrado. PeerJ 8:e9751

39. Garber JC, Barbee RW, Bielitzki JT (2011) Guide for the care and use of laboratory animals. Committee for the Update of the Guide for the Care and Use of Laboratory Animals. National Academies Press, Washington, DC

40. Glinski DA, Henderson WM, Van Meter RJ, Purucker ST (2018) Effect of hydration status on pesticide uptake in anurans following exposure to contaminated soils. Environ Sci Pollut Res 25:1619216201

41. Guerra C, Aráoz E (2016) Amphibian malformations and body condition across an agricultural landscape of northwest Argentina. Diseases of Aquatic Organisms 121:105-116

42. Gürkan M, Hayretdağ S (2012) Morphological and histological effects of copper sulfate on the larval development of green toad, Bufo viridis. Turkish Journal of Zoology 36:231-240

43. Hegde G, Krishnamurthy SV (2014) Analysis of health status of the frog Fejervarya limnocharis (Anura: Ranidae) living in rice paddy fields of Western Ghats, using body condition factor and AChE content. Ecotoxicology Environmental Contamination 9:69-76

44. Houlahan JE, Findlay CS, Schmidt BR, Meyer AH, Kuzmin SL (2000) Quantitative evidence for global amphibian population declines. Nature 404:752-755

45. Howarth FG (2000) Non-target effects of biological control agents. Biological control: measures of success. Springer, pp. 369-403

46. INTA (2008) Guia para cuidado y uso de animales para experimentación. Centro de Investigación en Ciencias Veterinarias, Instituto Nacional de Tecnología Agropecuaria (INTA), Secretaría de Agricultura, Ganadería, Pesca y Alimentación, Republica Argentina

47. IUCN (2020) The IUCN Red List of Threatened Species. Version 2020-3.. https://www.iucnredlist.org

48. Jackson DA (1993) Stopping rules in principal components analysis: a comparison of heuristical and statistical approaches. Ecology 74:2204-2214

49. Jha AN (2008) Ecotoxicological applications and significance of the comet assay. Mutagenesis 23:207-221 
50. Jolliffe IT, Cadima J (2016) Principal Component Analysis: A review and recent developments. Philosophical Transactions of the Royal Society A: Mathematical Physical Engineering Sciences 374:20150202

51. Josende ME, Tozetti AM, Alalan MT, Filho M, da Silva Ximenez V, da Silva Júnior S, Martins FMR, S.E (2015) Genotoxic evaluation in two amphibian species from Brazilian subtropical wetlands. Ecol Ind 49:83-87

52. Kawai K, Kaku K, Izawa N, Shimizu T, Fukuda A, Tanaka Y (2007) A novel mutant acetolactate synthase gene from rice cells, which confers resistance to ALS-inhibiting herbicides. Journal of Pesticide Science 32:89-98

53. Kegley SE, Hill BR, Orme S, Choi AH (2020) PAN Pesticide Database. Pesticide Action Network. PAN Pesticide Database website, Oakland. http:www.pesticideinfo.org

54. Kiesecker JM, Blaustein AR, Belden LK (2001) Complex causes of amphibian population declines. Nature 410:681-684

55. Köhler HR, Triebskorn R (2013) Wildlife ecotoxicology of pesticides: can we track effects to the population level and beyond? Science 341:759-765

56. Lajmanovich RC, Peltzer PM, Attademo AM, Colussi CL, Martinuzzi CS (2018) Blood biomarkers of common toad Rhinella arenarum following chlorpyrifos dermal exposure. Interdisciplinary toxicology 11:148-154

57. Leiva-Presa À, Jenssen M, B (2006) Effects of p, p'-DDE on retinoid homeostasis and sex hormones of adult male European common frogs (Rana temporaria). Journal of Toxicology Environmental Health Part A 69:2051-2062

58. Lin K, Xu C, Zhou S, Liu W, Gan J (2007) Enantiomeric separation of imidazolinone herbicides using chiral high-performance liquid chromatography. Chirality 19:171-178

59. Lowry OH, Rosebrough NJ, Farr AL, Randall RJ (1951) Protein measurement with the Folin phenol reagent. J Biol Chem 193:265-275

60. Magdaleno A, Gavensky MP, Fassiano AV, Ríos de Molina MC, Santos M, March H, Moretton J, Juárez ÁB (2015) Phytotoxicity and genotoxicity assessment of imazethapyr herbicide using a battery of bioassays. Environ Sci Pollut Res 22:19194-19202

61. Mann RM, Hyne RV, Choung CB, Wilson SP (2009) Amphibians and agricultural chemicals: Review of the risks in a complex environment. Environ Pollut 157:2903-2927

62. McDiarmid RW, Altig R (1999) Tadpoles: the biology of anuran larvae. University of Chicago Press

63. Medina RG, Ponssa ML, Aráoz E (2016) Environmental, land cover and land use constraints on the distributional patterns of anurans: Leptodacylus species (Anura, Leptodactylidae) from Dry Chaco. PeerJ 4:e2605

64. Moraes BS, Clasen B, Loro VL, Pretto A, Toni C, de Avila LA, Marchesan E, de Oliveira Machado SL, Zanella R, Reimche GB (2011) Toxicological responses of Cyprinus carpio after exposure to a commercial herbicide containing imazethapyr and imazapic. Ecotoxicol Environ Saf 74:328-335 
65. Newman MC (2014) Fundamentals of ecotoxicology: the science of pollution. CRC press, Boca Ratón

66. Ossana NA, Castañé PM, Salibián A (2013) Use of Lithobates catesbeianus tadpoles in a multiple biomarker approach for the assessment of water quality of the Reconquista river (Argentina). Arch Environ Contam Toxicol 65:486-497

67. Pasha F (2013) Enzyme Inhibition (AChE) in Brain of Oreochromis mossambicus due to Pesticidal Pollution of Herbicide Pursuit. Journal of Biological Sciences 1:91-100

68. Pasha F, Singh R (2005) Enzyme inhibition (AChE) in muscles and skin of Oreochromis mossambicus due to pesticidal pollution of herbicide Pursuit. Asian J Exp Sci 19:119-126

69. Păunescu A, Ponepal CM, Drăghici O, Marinescu AG (2010) Histopathological responses of the liver tissues of Rana ridibunda to the champions 50 wp fungicide. Annals Food Science Technology 11:60-64

70. Peltzer PM, Lajmanovich RC, Sánchez-Hernandez JC, Cabagna MC, Attademo AM, Bassó A (2008) Effects of agricultural pond eutrophication on survival and health status of Scinax nasicus tadpoles. Ecotoxicol Environ Saf 70:185-197

71. Pérez-Iglesias JM, Brodeur JC, Larramendy ML (2020) An imazethapyr-based herbicide formulation induces genotoxic, biochemical, and individual organizational effects in Leptodacty/us latinasus tadpoles (Anura: Leptodactylidae). Environ Sci Pollut Res 27:2131-2143

72. Pérez-Iglesias JM, Franco-Belussi L, Moreno L, Tripole S, de Oliveira C, Natale GS (2016) Effects of glyphosate on hepatic tissue evaluating melanomacrophages and erythrocytes responses in neotropical anuran Leptodactylus latinasus. Environ Sci Pollut Res 23:9852-9861

73. Pérez-Iglesias JM, Natale GS, Soloneski S, Larramendy ML (2018) Are the damaging effects induced by the imazethapyr formulation Pivot ${ }^{\circledR} \mathrm{H}$ in Boana pulchella (Anura) reversible upon ceasing exposure? Ecotoxicol Environ Saf 148:1-10

74. Pérez-Iglesias JM, Ruiz de Arcaute C, Natale GS, Soloneski S, Larramendy ML (2017) Evaluation of imazethapyr-induced DNA oxidative damage by alkaline Endo III-and Fpg-modified single-cell gel electrophoresis assay in Hypsiboas pulchellus tadpoles (Anura, Hylidae). Ecotoxicol Environ Saf 142:503-508

75. Pérez-Iglesias JM, Soloneski S, Nikoloff N, Natale GS, Larramendy ML (2015) Toxic and genotoxic effects of the imazethapyr-based herbicide formulation Pivot $\mathrm{H} \circledast$ on montevideo tree frog Hypsiboas pulchellus tadpoles (Anura, Hylidae). Ecotoxicol Environ Saf 119:15-24

76. Quaranta A, Bellantuono V, Cassano G, Lippe C (2009) Why amphibians are more sensitive than mammals to xenobiotics. PLoS One 4:e7699

77. Reimche GB, Machado SLO, Oliveira MA, Zanella R, Dressler VL, Flores EMM, Gonçalves FF, Donato FF, Nunes MAG (2015) Imazethapyr and imazapic, bispyribac-sodium and penoxsulam: Zooplankton and dissipation in subtropical rice paddy water. Sci Total Environ 514:68-76

78. Sanchez LC, Peltzer PM, Lajmanovich RC, Manzano AS, Junges CM, Attademo AM (2013) Reproductive activity of anurans in a dominant agricultural landscape from central-eastern Argentina. Revista Mexicana de Biodiversidad 84:912-926 
79. Schulte-Hostedde Al, Zinner B, Millar JS, Hickling GJ (2005) Restitution of mass-size residuals: validating body condition indices. Ecology 86:155-163

80. Selcer KW, Verbanic JD (2014) Vitellogenin of the northern leopard frog (Rana pipiens): development of an ELISA assay and evaluation of induction after immersion in xenobiotic estrogens. Chemosphere 112:348-354

81. Shutler D, Marcogliese DJ (2011) Leukocyte profiles of northern leopard frogs, Lithobates pipiens, exposed to pesticides and hematozoa in agricultural wetlands. Copeia 2011, 301-307

82. Sparling DW, Linder G, Bishop CA, Krest SK (2010) Ecotoxicology of Amphibians and Reptiles. SETAC Books, Boca Raton

83. Stebbins RC, Cohen NW (1995) A natural history of amphibians. Princeton University Press, Princeton

84. Suárez RP, Zaccagnini ME, Babbitt KJ, Calamari NC, Natale GS, Cerezo A, Codugnello N, Boca T, Damonte MJ, Vera-Candioti J (2016) Anuran responses to spatial patterns of agricultural landscapes in Argentina. Landscape Ecol 31:2485-2505

85. Tan S, Evans RR, Dahmer ML, Singh BK, Shaner DL (2005) Imidazolinone-tolerant crops: history, current status and future. Pest Manag Sci 61:246-257

86. USEPA (1975) Methods for acute toxicity tests with fish, macroinvertebrates, and amphibians. in: Agency UEP (ed). USEPA 660/3-75-009,62

87. USEPA (1989) Imazethapyr Herbicide Profile 3/89. Chemical Fact Sheet for Imazethapyr. United States Environmental Protection Agency, Office of Pesticide Programs, Washington DC, p 196

88. Vaira M, Akmentins M, Attademo M, Baldo D, Barrasso D, Barrionuevo S, Basso N, Blotto B, Cairo S, Cajade R, Céspedez J, Corbalán V, Chilote P, Duré M, Falcione C, Ferraro D, Gutierrez FR, Ingaramo MR, Junges C, Lajmanovich R, Lescano JN, Marangoni F, Martinazzo L, Marti L, Moreno L, Natale G, Pérez Iglesias JM, Peltzer P, Quiroga L, Rosset S, Sanabria E, Sanchez L, Schaefer E, Úbeda C, Zaracho V (2012) Categorización del estado de conservación de los anfibios de la República Argentina. Cuadernos de Herpetología 26, 131-159

89. Van der Oost R, Beyer J, Vermeulen NPE (2003) Fish bioaccumulation and biomarkers in environmental risk assessment: a review. Environ Toxicol Pharmacol 13:57-149

90. Van Meter RJ, Adelizzi R, Glinski DA, Henderson WM (2019) Agrochemical Mixtures and Amphibians: The Combined Effects of Pesticides and Fertilizer on Stress, Acetylcholinesterase Activity, and Bioaccumulation in a Terrestrial Environment. Environ Toxicol Chem 38:1052-1061

91. Van Meter RJ, Glinski DA, Henderson WM, Garrison AW, Cyterski M, Purucker ST (2015) Pesticide Uptake Across the Amphibian Dermis Through Soil and Overspray Exposures. Arch Environ Contam Toxicol 69:545-556

92. Van Meter RJ, Glinski DA, Hong T, Cyterski M, Henderson WM, Purucker ST (2014) Estimating terrestrial amphibian pesticide body burden through dermal exposure. Environ Pollut 193:262-268

93. Van Meter RJ, Glinski DA, Purucker ST, Henderson WM (2018) Influence of exposure to pesticide mixtures on the metabolomic profile in post-metamorphic green frogs (Lithobates clamitans). Sci Total Environ 624:1348-1359 
94. Vasseur P, Cossu-Leguille C (2003) Biomarkers and community indices as complementary tools for environmental safety. Environ Int 28:711-717

95. Venturino A, Pechen de D'Angelo AM (2005) Biochemical targets of xenobiotics: Biomarkers in amphibian ecotoxicology. Applied Herpetology 2:335-353

96. Vera Candioti J, Natale GS, Soloneski S, Ronco AE, Larramendy ML (2010) Sublethal and lethal effects on Rhinella arenarum (Anura, Bufonidae) tadpoles exerted by the pirimicarb-containing technical formulation insecticide Aficida ${ }^{\circledR}$. Chemosphere 78:249-255

97. Walker CH (2009) Organic pollutants: an ecotoxicological perspective. CRC Press, Boca Raton

98. Wang MZ, Jia XY (2009) Low levels of lead exposure induce oxidative damage and DNA damage in the testes of the frog Rana nigromaculata. Ecotoxicology 18:94-99

99. Zar JH (2010) Biostatistical Analysis, 5 edn. Prentice Hall, NewJersey

100. Zaya RM, Amini Z, Whitaker AS, Kohler SL, Ide CF (2011) Atrazine exposure affects growth, body condition and liver health in Xenopus laevis tadpoles. Aquat Toxicol 104:243-253

\section{Table}

Table 1. Endpoints at different ecological leveles evaluated in adults of Leptodactylus latinasus exposed to the atrazine-based herbicide formulation Pivot ${ }^{\circledR} \mathrm{H}$.

\begin{tabular}{llllll}
\hline \multicolumn{1}{c}{ Level } & \multicolumn{1}{c}{ End-point } & \multicolumn{3}{c}{96} \\
& Body condition & S1 & S2 & S1 & S2 \\
\hline Individual & Hepatosomatic index & ND & ND & ND & ND \\
& Liver tissue alterations & ND & ND & $(-)^{*}$ & $(-)^{*}$ \\
\hline Histological & HV & ND & $(+)^{*}$ & ND & $(+)^{*}$ \\
& ES & ND & $(+)^{*}$ & ND & $(+)^{*}$ \\
& M & ND & ND & ND & ND \\
& MMCs pigmentation & ND & ND & ND & ND \\
& Melanin & & & & \\
& Hermosiderin & ND & ND & $(-)^{*}$ & $(-)^{*}$ \\
& GSH & ND & ND & $(-)^{*}$ & ND \\
\hline Biochemical & GST & ND & ND & ND & ND \\
& CAT & $(-)^{*}$ & ND & ND & ND \\
& AChE & ND & ND & $(+)^{*}$ & ND \\
& $M N s$ & ND & $(+)^{*}$ & ND & ND \\
\hline Celullar & Nuclear abnormalities & ND & ND & $(+)^{*}$ & ND \\
& ND & ND & ND & ND \\
\hline
\end{tabular}

Response or function of biomarkers respect to control group with stimulation or increase (+) and inhibition or decrease (-). ND: not detected effect. S1; corresponds to runoff scenario at $10 \mathrm{mg} / \mathrm{L}$, while S2; correspond to direct spray application at $1000 \mathrm{mg} / \mathrm{L} . *, \mathrm{p}<0.05 ; * *, \mathrm{p}<0.01$; significant differences with respect to control. Hyper Vascularization (HV), Enlargement of Sinusoids (ES), Mononuclear cell Infiltration (MI), Vacuolization 
(V), Melanomacrophages (MMCs), Reduced Gluthatione (GSH), Gluthatione-S-Transferase (GST), Catalase (CAT), Acetylcholinesterase (AChE), and Micronucleus (MNs).

\section{Figures}
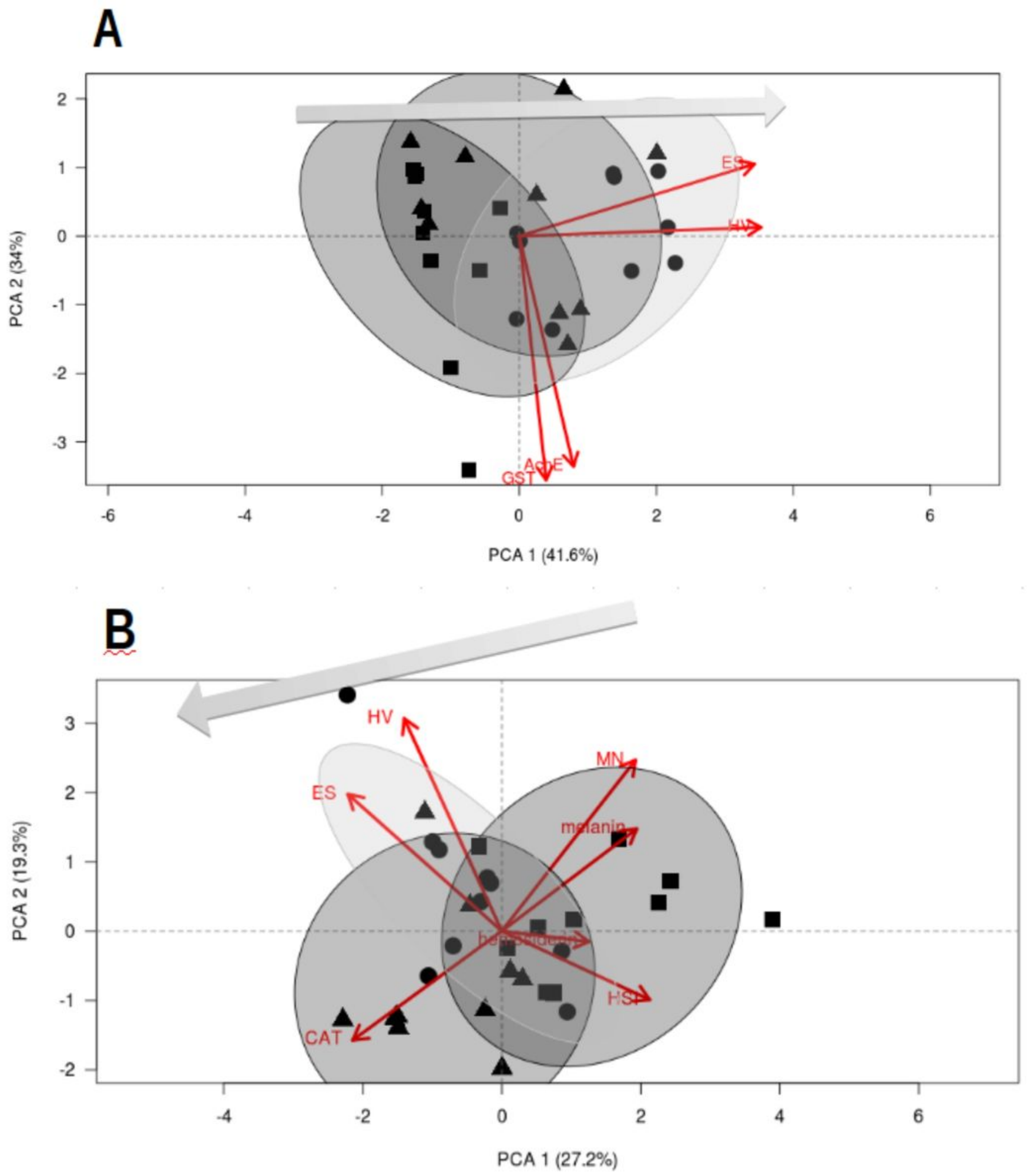


\section{Figure 1}

Biplot representing the responses of each biomarker evaluated in Leptodactylus latinasus adults exposed to the simulating scenarios of exposure to the imazethapyr-based commercial herbicide Pivot ${ }^{\circledR} \mathrm{H}$ after 48 (A) and $96 \mathrm{~h}(\mathrm{~B})$. The wide gray white arrow shows the increasing concentration gradient for control group and each scenario of IMZT exposure such as control group (squares), runoff simulation or $10 \mathrm{mg}$ IMZT/L (triangles), and direct spraying application or $1000 \mathrm{mg}$ IMZT/L 0.22 (circles) obtained by the correlation between the biomarkers. Circles showed groupings of each treatment on an IMZT gradient. The length of the red arrow indicates the magnitude of the response of the different biomarkers. AChE, acetylcholinesterase; CAT, catalase; ES, enlargement of sinusoids; GST, gluthatione-S-transferase; $\mathrm{HSI}$, hepatosomatic index; HV, hypervascularization; MNs, micronuclei. 